\title{
STUDY ON ZOOPLANKTON DIVERSITY DURING SPRING SEASON IN CHASHMA LAKE, PAKISTAN
}

\author{
*HAYAT $S^{1,3}$, NAEEM $M^{2}$, RAMZAN $M^{3}$, ZAFARULLAH $M^{3}$, AHMAD I ${ }^{3}$, ALI $Q^{1}$, MALIK ${ }^{1}$ \\ ${ }^{1}$ Institute of Molecular Biology and Biotechnology, The University of Lahore, Lahore, Pakistan \\ ${ }^{2}$ Institute of Pure and Applied Biology, Bahauddin Zakariya University, Multan, Pakistan \\ ${ }^{3}$ Fish Biodiversity Hatchery Punjab Fisheries Department, Chashma, Mianwali, Pakistan \\ Corresponding author E-mail: skndrhayat93@gmail.com
}

(Received, $9^{\text {th }}$ March 2020, Accepted $11^{\text {th }}$ May 2020)

\begin{abstract}
The present study was conducted to know the zooplankton species diversity in Chashma Lake during spring (March 2016 to May 2016). Various physico-chemical parameters like Temperature, PH, Salinity, conductivity, Total dissolved solids (TDS), Turbidity, Dissolved Oxygen, Alkalinity, Chloride and Carbon dioxide which effect the distribution of zooplankton were also analyzed during this study. Zooplankton community was dominated by different species of rotifers. Those rotifers were Asplanchna herricki, Asplanchna brightwelli, Polyarthra remata, Brachionus angularis, Keratella cochlearis, Keratella tecta and Keratella valga tropica. Among these Keratella valga tropica was most common. Some species of copepods were recorded such as, Diacyclops thomasi, Acanthocyclops robustus, Mesocyclops edax, Tropocyclops prasinus mexicanus and Orthocyclops modestus. Among these Diacyclops thomasi was most abundant. Among copepods some nauplii and copepodid stages were also observed. Different species of cladocerans such as, Bosmina longirostris, Daphnia pulex, Chydorus sphaericus, Alona bicolor, Alonella exigua and Simocephalus serrulatus were also recorded.
\end{abstract}

Keywords: Zooplankton, Diversity, Chashma Lake, Copepodes, cladocerans

\section{Introduction}

Zooplanktons are of great importance in fresh and marine aquatic ecosystem. Zooplanktons migrate in dual way, during day time they come upward to follow the prey and go downward to hide themselves from predators (Castro and Huber, 2012). Chashma Lake, with respect to its surface area is the $3{ }^{\text {rd }}$ biggest Lake of Pakistan. It is situated at GPS N32 26.110 $\mathrm{E} 071^{\circ} 25.571$ and at elevation of 640 feet. Its area under water is $360 \mathrm{Km}^{2}$, Gross storage capacity at elevation 649 feet is $0.321 \mathrm{MAF}$, Water surface area is 88900 acres and main water supply source is mighty River Indus. The River Indus supports a major bulk of the population living in this part of the world. More than 80 per cent of Pakistan's agricultural wealth and food production is derived from the river Indus which has been called the "life line" of Pakistan (Meadows and Meadows, 1999). Water is fundamental in the evolution of all living organisms and is one of the basic compounds without which life in any form is not possible in this world. Aquatic life requires water as a support system and as a medium in which it moves and obtains oxygen in dissolved form. Terrestrial life also requires a regular supply of water to maintain its biological processes. It is the most essential and abundantly available substance in nature (Templeton, 1984). Zooplanktons are minute organisms which float in the water surface along with water current. They occupy an intermediate position in the food web. The importance of zooplanktons as fish food both for adults and fry has been stressed by different workers (Geiger, 1983; Fontaine and Revera, 1986). The presence and dominance of zooplankton species play very significant role in the functioning of fresh water ecosystems. The seasonal changes in zooplankton species are closely related to the physico-chemical and biological administration of the aquatic environments. Species of Rotifer and Cladocerans are suggested as indicators that can be used to identify different physical and chemical gradients or eutrophic increases in reservoirs (Branco et al., 2002).

Zooplankton not only transfer energy from primary producers to higher order consumers like macro crustaceans, insects and small fish but some species are considered good indicators of trophic status of water bodies. No proper work on zooplankton diversity in Chashma Lake has so far been done.

[Citation: Hayat, S., Naeem, M,. Ramzan, M., Zafarullah, M., Ahmad, I., Ali, Q., Malik, A. (2020). Study on zooplankton diversity during spring season in Chashma Lake, Pakistan. Biol. Clin. Sci. Res. J., 2020: 9 doi: https://doi.org/10.54112/bcsrj.v2020i1.9]. 
However, some notable work on freshwater zooplankton in Pakistan was done by (Baqai et al., 1974; Akhter and Ali, 1976; Iqbal and Kazmi, 1990; Mahar et al., 2000; Baloch, et al., 2000; Baloch and Soomro, 2004; Baloch et al., 2004). The present study primarily aims to document the seasonal distribution of zooplankton species in Chashma Lake especially during spring season.

\section{Materials and Methods}

\section{Study site}

Chashma lake was the study site of the present study $\left(\mathrm{N} 32^{\circ} 26.110 \mathrm{E} 071^{\circ} 25.571\right)$

\section{Water Sampling}

The physical and chemical properties of water enormously influenced the distribution and fertility of aquatic life (Unanam and Akpan, 2006). Samples for water quality and zooplankton study were collected fortnightly from March 2016 to May 2016 two times i.e. Dawn and Dusk. The sampling was carried out from the surface area at three different locations at GPS (1) N32026.110, E071025.571, (2) N32 26.229 , E071023.664, (3) N32027.141, E071020.919 using GARMIN GPS map 76CSX.

Following characteristics of water were analyzed in the study to check the quality of water for planktonic life:

1. Physical Characteristics: The physical characteristics included water temperature, salinity, conductivity, total dissolved solids (TDS) and turbidity.

2. Chemical Characteristics: The chemical characteristics included $\mathrm{pH}$, dissolved oxygen (DO), alkalinity, Chloride and Carbon dioxide.

All the physical parameters were noted at the spot by dipping the probe of digital meters in water. Measurements of water temperature were made at each station with a digital thermometer with stainless steel sensor probe (WT-1). The measurements were taken directly from the water body by dipping the probe of the thermometer into the water avoiding direct exposure to sunlight (Welch, 1952) and allowing it to stay for at least five minutes. This was to allow for accuracy in measurements. The results were taken and recorded accordingly. $\mathrm{PH}$ was measured using digital $\mathrm{pH}$ meter (Ecosense PH100). Probe of digital meter was dip into the water and wait till the stable display of reading and value was noted in the performa. Same process was repeated at each station.

Salinity, Electric conductivity and total dissolved solid (TDS), were recorded using portable meter, (Ecosense EC300) by dipping its probe directly into water at each station and stable display of reading was noted in the Performa. For turbidity EUTECH turbid meter (TN-100) was used by putting the aliquot filled with water sample into the turbidity meter chamber and reading was noted. Dissolved oxygen was recorded using Lutron DO-5510 digital meter by putting its probe directly in the water. The water samples for chemical analysis were collected in air tight plastic bottles having capacity of 1 liter. These samples were then brought into Fish Biodiversity Hatchery chashma Barrage laboratory for further analysis. Chemical parameters such as Alkalinity, Chloride, and Carbon dioxide were analyzed using $\mathrm{HACH}$ test kit (model FF-1A) readings of these parameters were noted in the prescribed performa. The important physical and chemical parameters influencing the aquatic environment are temperature, $\mathrm{pH}$, salinity, dissolved oxygen and carbon dioxide and these parameters are the limiting factors for the survival of aquatic organisms (Lawson, 2011).

\section{Zooplankton Sampling}

Zooplankton samples were collected with a round silk cloth net of mesh size about $60 \mu \mathrm{m}$. The diameter of the net was $10 \mathrm{~cm}$ held open by a metal frame and attached to with a $250 \mathrm{ml}$ bottle attached to the distal end. For qualitative and quantitative plankton sampling, 100 liters of water were poured into net to concentrate the sample. The samples were preserved on the spot with $5 \%$ formalin and were assembled in one sample. All the zooplanktons were identified up to species or genera level, using keys and illustrations given by (Ward and Whipple, 1959; Mizuno, 1964; Mizuno and Takahashi, 1991; Battish, 1992). The following taxonomic keys were also used in zooplankton identification: Rotifera (Koste, 1978; Segers, 1993; Segers et al., 1993), Cladoceran (Jeje and Fernando, 1986; Korovchinsky, 1992), Copepoda (Jeje, 1988, Williamson, 1991; Ueda and Reid, 2003). Quantitative estimate of zooplankton was done under the LCD Digital microscope (Celestron Model\#44340) at $100 \mathrm{x}$ magnifications. Relative abundance of major zooplankton species were enumerated by counting the samples of $1 \mathrm{ml}$ using Sedgwick-Rafter counting cell (S52). For quantitative analysis whole samples were analyzed and counted. During the present study it was observed that rotifers contributed $38.88 \%$, cladocerans $33.33 \%$ and copepods $27.77 \%$ among the zooplankton community.

\section{Results and Discussion}

The quality of natural water is generally governed by various physico-chemical and biological parameters. The mean values for various parameters during the study period are presented in Table 1 . The variations in temperature of reservoir water were observed in spring season (March 2016 to May 2016). The temperature values ranged between 22.9 to $29.9^{\circ} \mathrm{C}$. Steady changes in the atmospheric temperature with the change in the seasons results in the corresponding change in the water temperature. High summer temperature and bright sunshine accelerate the

[Citation: Hayat, S., Naeem, M,. Ramzan, M., Zafarullah, M., Ahmad, I., Ali, Q., Malik, A. (2020). Study on zooplankton diversity during spring season in Chashma Lake, Pakistan. Biol. Clin. Sci. Res. J., 2020: 9 doi: https://doi.org/10.54112/bcsrj.v2020i1.9]. 
process of decay of organic matter resulting into the liberation of large quantities of $\mathrm{CO}_{2}$ and nutrients. The $\mathrm{pH}$ is affected not only by the reaction of carbon dioxide but also by organic and inorganic solutes present in water. Any change in water $\mathrm{pH}$ is complemented by the change in other physicochemical parameters. $\mathrm{PH}$ maintenance is one of the most important characteristics of any aquatic system since all the biochemical activities depend on $\mathrm{pH}$ of the surrounding water. The lake water was slightly alkaline having $\mathrm{pH}$ ranging from 8.2 to 8.4. According to Previous studies, $\mathrm{pH}$ value does not increase more than 8.5 (Ahmed et al., 1985; Leghari et al., 2004). PH values recorded were favorable for zooplankton production as they are not anywhere close to death points for zooplankton.

In present study the value of salinity was found to be 0.1 ppt. During this study period, it was observed there was no fluctuation in salinity value at any station. Change in salinity can affect biota in fresh water directly or indirectly. Toxic effects as a consequence of increasing salinity cause physiological changes resulting in loss or gain of species. Indirect change can occur where increasing salinity modifies community structure and function by removing or adding texa that provide refuge, food or modify predation pressure. Other factors such as water- logging or loss of habitat may interact with salinity or have more abrupt impact on species richness (Savage, 1979; Clunie et al., 2002).

Electric conductivity ranged from 294.5 us to349.5us during the present study. Water quality indicated that this lake is in early stage of eutrophication (Ahmed et al., 1985). According to Vajrappa and Singh (2005), water having conductivity below $750 \mu \mathrm{mhos} / \mathrm{cm}$ is satisfactory. In this study, conductivity level can be said to be within the limit hence, favorable for the growth of phytoplankton upon which zooplankton feed. The total dissolved solids (TDS) were recorded as $0.1661 \mathrm{gm} / 1-0.2232 \mathrm{gm} / \mathrm{l}$. The values of TDS were maximum in the month of April (Sabata and Nayar, 1995). The value of turbidity ranges between 4.71NTU to 13.22 NTU. The increased turbidity during rainy months was attributed to soil erosion in the nearby catchment and massive contribution of suspended solids from sewage. Surface runoffs and domestic wastes mainly contribute to the increased turbidity of the reservoir. But in this region the suspended solids play an important role in governing the turbidity, which enter the reservoir through land erosion.

Dissolved oxygen (DO) is a very important parameter of water quality and index of physical and biological process going on in water. In the present study, the dissolved oxygen concentration ranged from $7.8 \mathrm{mg} / \mathrm{l}$ to $8.6 \mathrm{mg} / \mathrm{l}$ ) was recorded in the month of May after the snow melting due to rainfall, which favours solubility of oxygen among the study sites. DO is of great importance to all living organisms. It may be present in water due to direct diffusion from air and photosynthetic activity of autotrophs. Concentration of DO is one of the most important parameters to indicate water purity and to determine the distribution and abundance of various planktons.

Alkalinity of water is a measure of weak acid present in it and of the cations balanced against them. Alkalinity plays an important role in controlling enzyme activities. In the present study alkalinity value was between $120.6 \mathrm{mg} / \mathrm{l}$ to $128.2 \mathrm{mg} / \mathrm{l}$. Different values of alkalinity on different sites of the present study showed variations in different months. Venkateswarlu (1969) recognized that there is an indication to suggest that alkalinity concentration is affected directly by rainfall. Similar effect has been noticed in the present investigation immediately often the onset of rains. Man-made water bodies usually show wide range of fluctuation in alkalinity values depending upon a number of factors. According to Michael (1969), alkalinity concentration is affected directly by rainfall. In the present investigation also, alkalinity level reduced in the post-rainy months. Higher level of alkalinity during summer months as observed in most of the sites has also been reported by Singh and Saha (1987).

Chloride is one of the important indicators of pollution. Chlorides are present in sewage, effluents and farm drainage. The observed values of chloride during the present study ranged from $78.3 \mathrm{mg} / \mathrm{l}$ to $88.3 \mathrm{mg} / \mathrm{l}$. The average value of chloride recorded $82.1 \mathrm{mg} / \mathrm{l}$. The seasonal trend in the chloride was found to be same during present investigation. $\mathrm{CO}_{2}$ values in Chashma Lake water ranged from $12.3 \mathrm{mg} / \mathrm{l}$ to $13.0 \mathrm{mg} / \mathrm{l}$ and remained quite normal during entire period of study. The limit of $\mathrm{CO}_{2}$ as per acceptable standards value $10 \mathrm{mg} / 1$ of surface water and increase in $\mathrm{CO}_{2}$ above this level indicates increase in pollution load (Koshy and Nair, 1999). Dwivedi and Sonar (2004) observed an average of $2 \mathrm{mg} / \mathrm{l}$ of free $\mathrm{CO}_{2}$ in water of a reservoir. Radhika et al., (2004) reported an annual variation of 2.42 to $10.47 \mathrm{mg} / 1$ of $\mathrm{CO}_{2}$ in Vellayani Lake in Kerala. The same author found that there was a gradual change in concentration ofCO $\mathrm{C}_{2}$ in the Lake from pre-monsoon to monsoon to post monsoon. In this study, it was found that the physico-chemical parameters of the reservoirs tested were not harmful for the survival of zooplanktons, rather they were significant in the improvement of productivity. Measurements of the concentrations of the parameters are within permissible limits. A total of 18 zooplankton species were identified during present study. These included 7 species of rotifera, 6 species of cladocera and 5 species of copepod (Table 2). Among rotifers Keratella valga tropica was most common. The other

[Citation: Hayat, S., Naeem, M,. Ramzan, M., Zafarullah, M., Ahmad, I., Ali, Q., Malik, A. (2020). Study on zooplankton diversity during spring season in Chashma Lake, Pakistan. Biol. Clin. Sci. Res. J., 2020: 9 doi: https://doi.org/10.54112/bcsrj.v2020i1.9]. 
rotifer species Asplanchna herricki, Brachionus angularis, Keratella cochlearis, Keratella tecta, Asplanchna brightwelli and Polyarthra remata were rare in zooplankton community.

Apart from rotifera, six species of cladocera were also seen in the lake, these were Bosmina longirostris, Daphnia pulex, Chydorus sphaericus, Alona bicolor, Alonella exigua and Simocephalus serrulatus. From quantitative analysis it was observed that both species Bosmina longirostris and Daphnia pulex were dominant in the lake and nearly in equal density. While others species of cladocera were common in the lake. The dominance of $D$. pulex and the low relative abundance of other Daphnia species suggest the absence of effective fish predation, even though all ponds contained fish. Low fish predation leads to the dominance of large cladocerans either through competitive superiority of large species (Hall et al., 1976; Gliwicz, 1990).

Five species of copepod were also present in the Lake, these included Diacyclops thomasi that contributed with higher population. Acanthocyclops robustus, Tropocyclops prasinus mexicanus, Mesocyclops edax and Orthocyclops modestus were also present with low populations. Relative lower copepod population suggests that it is not a food-poor environment and hence Cladocera are more successful. The rotifers are adaptable in nature and appear and disappear within a very short period of time. The community structure of zooplankton showed a mixed composition of mesotrophic to eutrophic species. Mostly the Brachionous species are also found in eutrophic environments (Hakkari, 1978; Gannon and Stemberger, 1978; Maemets, 1983; Baloch et al., 2004). On the other hand, species like $K$. valga tropica is found in mesotrophic environments and is abundant in riverine systems (Beach, 1960; Baloch et al., 2000; Baloch and Soomro, 2004). Abundance of mesotrophic species, $K$. valga tropica revealed that the lake is not yet completely eutrophic. However, presence of eutrophic indicator species, $K$. cochlearis and $K$. tecta indicated that the trend is going from mesotrophic to eutrophic. Among Cladocerans, $B$. lorzgirostris and Daphnia pulex are lacustrine species, former occurs usually in mesotrophic to eutrophic environments (Swar and Fernando, 1980).

During the present study, it was observed that mainly water temperature regulates the density and diversity of dominant zooplankton population in the freshwater. During this study period, it was observed that water temperature ranged from 22.9 to $29.9^{\circ} \mathrm{C}$ which was suitable for all studied zooplankton. Evidence suggests zooplanktons are more sensitive to changes in temperature than phytoplankton in other environments. For example, moderate warming enhances the growth and feeding rates of many filter-

feeding zooplankton species, such as some Daphnia sp. (McKee and Ebert 1996). Warmer temperature can favor smaller zooplankton at developmental stages. In addition, large cladocerans and copepods may show reduced fecundity at elevated temperatures. Zooplankton abundance declined because lethal increases in water temperatures above $45^{\circ} \mathrm{C}$ resulted in crustacean species being replaced by smaller rotifers (Strecker et al., 2004; Taylor and Mahoney, 1988). From the zooplankton community structure of Chashma Lake it can be concluded that it is a slightly mesotrophic lake rapidly changing to eutrophic stage. Further studies of zooplankton on seasonal basis are required for better understanding of the lake environment. Conductivity, salinity and water temperature showed significant correlation ship with zooplankton abundance (AbdAllah et al., 2017).

Table 1. Values of different Physico-chemical parameters of Chashma lake during spring season (March 2016 to May 2016)

\begin{tabular}{llll}
\hline $\begin{array}{l}\text { Sr. } \\
\text { No }\end{array}$ & \multicolumn{1}{c}{ Parameter } & Unit & Value Range \\
\hline 1 & Water & & \\
& Temperature & & $22.9-29.9$ \\
2 & PH & & $8.1-8.4$ \\
3 & Salinity & $(\mathrm{ppt})$ & $0.1-0.1$ \\
4 & Conductivity & $(\mathrm{us})$ & $294.5-349.5$ \\
5 & T.D. S & $(\mathrm{gm} / \mathrm{L})$ & $0.1661-0.2232$ \\
6 & Turbidity & $(\mathrm{NTU})$ & $4.71-13.22$ \\
7 & Dissolved Oxygen & $(\mathrm{mg} / \mathrm{L})$ & $8.5-8.6$ \\
8 & Alkalinity & $(\mathrm{mg} / \mathrm{L})$ & $120.6-128.2$ \\
9 & Chloride & $(\mathrm{mg} / \mathrm{L})$ & $78.3-88.3$ \\
10 & Carbon Dioxide & $(\mathrm{mg} / \mathrm{L})$ & $10.4-13.0$ \\
\hline
\end{tabular}

Table 2. Zooplankton species and their occurrence in Chashma lake in spring season (March 2016 to May 2016)

\begin{tabular}{lcc}
\hline Sr. No & Zooplankton & Occurrence \\
\hline Rotifera & \\
1 & Asplanchna herrick & + \\
2 & Brachionus angularis & + \\
3 & Keratella cochlearis & ++ \\
4 & Keratella tecta & + \\
5 & Keratella valga tropica & +++ \\
6 & Asplanchna brightwelli & ++ \\
7 & Polyarthra remata & + \\
Cladocera & \\
8 & Bosmina longirostris & ++++ \\
9 & Daphnia pulex & ++++ \\
10 & Chydorus sphaericus & +++ \\
11 & Alona bicolor & ++ \\
12 & Alonella exigua & ++ \\
13 & Simocephalus serrulatus & +++ \\
Copepoda & \\
14 & Diacyclops thomasi & +++ \\
15 & Acanthocyclops robustus & ++ \\
16 & Tropocyclops prasinus & ++ \\
& mexicanus & + \\
\hline
\end{tabular}

[Citation: Hayat, S., Naeem, M,. Ramzan, M., Zafarullah, M., Ahmad, I., Ali, Q., Malik, A. (2020). Study on zooplankton diversity during spring season in Chashma Lake, Pakistan. Biol. Clin. Sci. Res. J., 2020: 9 doi: https://doi.org/10.54112/bcsrj.v2020i1.9]. 


\begin{tabular}{lll}
\hline 17 & Mesocyclops edax & ++ \\
18 & Orthocyclops modestus & ++ \\
\hline
\end{tabular}

++++ Abundant +++ fairly present ++ common +

rare

\section{Conflict of interest}

The authors declared the absence of any conflict of interest.

\section{References}

AbdAllah, T.A., Adel, A., Mohammad, J.K.S., Sahar, H.H., Mohammed, S., and Abdel, D. (2017). Seasonal Abundance of Zooplankton at Mangrove and Sandy Shore Habitat at Almarjan Zone, Jazan. Atmospheric and Oceanic Sciences, 2(4): 102-108.

Ahmed, M.M., Barlas, A. and Iqbal, Q.J. (1985). Some Physico-chemical variables of Rawal, lake Islamabad. Pak. J. Zool., 17(3): 313-316.

Akhter, S. and Ali, S.R. (1976). The rotifers of Pakistan I. Bull. Hydrobiol. Res. Gordon College Ser. 1(1): 12-122.

Baloch, W.A. and Soomro, A.N. (2004). Rotifers of the adjacent areas of Hyderabad, Sindh. Pak. J. Zool. 36(4): 319-322.

Baloch, W.A., Soomro, A.N. and Jafri, S.I.H. (2004). Zooplankton of highly saline water, near Hyderabad. Sind. Univ. Res. Jour. (Sci. Ser.)., 36(1): 25-28.

Baloch, W.A., Suzuki, H. and Onoue, Y. (2000). Occurrence of planktonic rotifer Filinia longiseta in Southern Kyushu, Japan. Pak. J. Zool., 32(3): 279-281.

Baqai, I.U., Siddiqui, P.A. and Iqbal, M. (1974). Limnological studies of Haleji lake. Agri. Pakistan. 2: 321-344.

Battish, S.K. (1992). Freshwater Zooplankton of India. Oxford and IBH Publishing Co. Pvt. Ltd.

Branco, C.W.C., Mariea-Isabel, A. R., Pinto, G.F.S., Gomaro, G.A. and de Filippo., R., (2002). Limnological features of Funil reservoirs (R.J. Brazil) and indicator properties of rotifers and cladocerans of the zooplankton community of lakes and reservoirs. Res. and Manag. 7: 187192.

Castro, P. and Huber, M. (2012). Marine Biology. Ninth Edition. McGraw Hill publishers. FAO, 2006. Mangrove, description, Saudi Arabia. www.FAO.org

Clunie, P., Ryan, T., James, K. and Cant, B. (2002). Implications for rivers from salinity hazards: Scoping Stusy. Report produced for the Murray Darling Basin commission, Strategic Investigations and Riverine Program Project R2003. Department of Natural resources and Environment, Vic.
Delhi, N., and Beach, N.W. (1960). A study of the planktonic rotifers of the Presque Isle County, Michigan. Ecol. Monogr. 30: 339-357.

Dwivedi, P., and Sonar, S. (2004). Evaluation of Physico-chemical and biological characteristics of water samples in water reservoir around Rono Hills, Doimmukh (Dist. Pampum Pare), Arunachal preadesh, Pollution Research. 23(1): 101-104.

Fontaine, C.T. and Revera, D.B. (1986). The mass culture of rotifers, Branchionu splicatalis, for use as food stuff in aquaculture. Proc. World Mariculture Soc. 11: 211-218.

Gannon, J.E., and Stemberger, R.S. (1978). Zooplankton, (Especially crustaceans and rotifers) as indicator of water quality. Trans Anz Illicros Soc. 97: 16-35.

Geiger, J.G., (1983). A review of ponds zooplankton productions fertilization for the culture of larval and fingerlings. Aquaculture. 36: 353360.

Gliwicz, M.Z., (1990). Food thresholds and body size in Cladocera. Nature. 343: 638-640.

Hakkari, L., (1978). On the productivity and ecology of zooplankton and its roleas food for fish in some lakes in central Finland. Biol. Res. Rep. Univ. Gyvaskyla. 4: 3-87.

Hall, D.J., Threlkeld, S.T., Burns, C.W. and Crowley, P.H., (1976). The size-efficiency hypothesis and the size structure of zooplankton communities. Annu. Rev. Ecol. Syst. 7: 177208.

Iqbal, M., and Kazmi, M.A. (1990). Cladocera of Hub lake with notes on species and size composition. Sarlzad J. Agri. 6: 85-88.

Jeje, C.Y. and Fernando, C.H. (1986). A practical guide to the identification of Nigerian zooplankton. Kainji Lake Research Institute, Niger, Nigeria.

Jeje, C.Y., (1988). A revision of the Nigerian species of the genera MesocyclopsSars, 1914 and Thermocyclops Kiefer, 1927 (Copepoda: Cycloida). Hydrobiologia. 164: 171-184.

Korovchinsky, N., (1992). Introduction to the Cladocerans manual for the 1992-1993 International Training Course at University of Gent, Gent. Netherland.

Koshy, M., and Nair, T.V. (1999). Water quality aspects of River Pampa, Pollution Research. 18(4): 501-510.

Koste, W., (19780. Rotatoria. Die Radetiere Mitteleuropas. Bestimmungs werkbegrundet von Max Voigt. Borntraeger, Stuttgart, Germany.

Lawson, E.O., (2011). Physico-Chemical Parameters and Heavy Metal Contents of Water from the

[Citation: Hayat, S., Naeem, M,. Ramzan, M., Zafarullah, M., Ahmad, I., Ali, Q., Malik, A. (2020). Study on zooplankton diversity during spring season in Chashma Lake, Pakistan. Biol. Clin. Sci. Res. J., 2020: 9 doi: https://doi.org/10.54112/bcsrj.v2020i1.9]. 
Mangrove Swamps of Lagos Lagoon, Lagos, Nigeria, Adv. Biol. Res. 5: 08-21.

Leghari, M.K., Leghari, M.Y., and Leghari, S.M. (2004). Water chemistry and its relationship with algae of Rawal Dam, Islamabad and Wah garden, District Attock. Sind. Univ. Res. Jour. (Sci. Ser.). 36(2): 29-48.

Maemets, A., (1983). Rotifers as indicators of Lake types in Estonia. Hydrobiologia 104: 357-361.

Mahar, M.A., Baloch, W.A. and Jafri, S.I.H. (2000). Diversity and seasonal occurrence of planktonic rotifers in Manchar lake, Sindh, Pakistan. Pakistan. J. fish. 1(1): 25-32.

McKee, D., and Ebert, D. (1996). The interactive effects of temperature, food level and material phenotype on offspring size in Daphnia magna. Oecologia. 107: 189 -196.

Meadows, A. and Meadows, P.S. (1999). The Indus River Biodiversity resources humankind. 1st ed. Oxford University Press, 5- Banglore Town, Sharae Faisal, Karachi.

Michael, R.G., (1969). Seasonal trends in physicochemical factors and plankton of freshwater fish pond and their role in fish culture. Hydrobiologia. 33. 145-60.

Mizuno, T., and Takahashi, E. (1991). An illustrated guide to Freshwater Zooplankton in Japan. Tokai University Press.

Mizuno, T., (1964). Illustrations of freshwater plankton of Japan. Hoikusha.

Radhika, C.G., Mini, I. and Gangadevi, T. (2004). Studies on Abiotic parameters of atropical fresh water lake Vellayani Lake, Trivandrum, Kerala. Pollution Research. 23(1): 49-63.

Sabata, B.C., and Nayar, M.P., (1995). River pollution in India: a case study of Ganga River. APH Pub. Corp. 33.

Savage, A.A., (1979). The Carixidae of an inland saline lake from 1970 to1975. Aichiv fur Hydrobiologie. 86: 355-370.

Segers, H., 1993. Rotifera of some lakes in the floodplain of the River Niger (Imo State, Nigeria). I. New species and other taxonomic considerations. Hydrobiologia. 250: 39-61.

Segers, H., Nwandiaro, S.C. and Dumont, H.J. (1993). Rotifera of some lakes in the floodplain of the River Niger (Imo State, Nigeria). Hydrobiologia. 250: 63-71.

Singh, B. and Saha, P.K. (1987). Primary productivity in a composite fish culture pond at Kulia fish farm, Kalyani, West Bengal. Prod Nat Acad Sci India. 57: 124-30.

Strecker, A.L., Cobb, T.P., and Vinebrooke, R.D. (2004). Effects of experimental greenhouse warming on phytoplankton and zooplankton communities in fishless alpine ponds, Limnol Oceanogr. 49 (4): 1182-1190.
Swar, B.D., and Famando, C.H. (1980). Some studies on the ecology of limnetic crustaceaus zoolplankton in lakes Begeras and Recepa, Pakhara Valley, Nepal. Hyderobiolog. 70: 235-245.

Taylor, B.E. and Mahoney, D.L. (1988). Extinction and recolonization: Processes regulating zooplankton dynamics in a cooling reservoir. verh. Inter Limnol. 23: 1536-1541.

Templeton, R.G. (1984). Freshwater fisheries management. Fishing News Book Limited Farnham Surrey. England.

Ueda, H., and Reid, W.J. (2003). Copepoda: Cyclopoida, Genera Mesocyclops and Thermocyclops Backhuys Publishers, Leiden, Netherlands.

Unanam, A.E., and Akpan, A.W. (2006). Analysis of physicochemical characteristics of some freshwater bodies in Essien Udim Local Government area of Akwalbom State, Nigeria, In: Proceeding of the 21st Annual Conference of the Fisheries Society of Nigeria (FI50N) Calabar, 13th -17th November.

Vajrappa, H.C., and Singh, N.R. (2005). Hydrochemical studies of Suvarna mukhisubbasin of Arkavathi river, Bangalore district, Karnataka. In: Fundamentals of Limnology.S.B. Nangia for APH Publishing Corporation 5, Ansari road, Darya Ganj, New Delhi, 171-181.

Venkateswarlu, V., (1969). An ecological study of the algae of the river Moosi, Hyderabad (India) with special reference to water pollution-I: Physico-chemical complexes. Hydrobiologia, 33,117-43.

Ward, H.B., and Whipple, G.C. (1959). Fresh water Biology. John Wiley and Sons.

Welch, P.S. (1952). Limnology Second Edition. McGraw Hill, Book Co. New York and London.

Williamson, C.E. (1991). Ecology and classification of North American freshwater invertebrates. In. J.H, 125-188. Thorp \& A.P. Cov

\section{(c) (†) (8)}

Open Access This article is licensed under a Creative Commons Attribution 4.0 International License, which permits use, sharing, adaptation, distribution and reproduction in any medium or format, as long as you give appropriate credit to the original author(s) and the source, provide a link to the Creative Commons licence, and indicate if changes were made. The images or other third party material in this article are included in the article's Creative Commons licence, unless indicated otherwise in a credit line to the material. If material is not included in the article's Creative Commons licence and your

[Citation: Hayat, S., Naeem, M,. Ramzan, M., Zafarullah, M., Ahmad, I., Ali, Q., Malik, A. (2020). Study on zooplankton diversity during spring season in Chashma Lake, Pakistan. Biol. Clin. Sci. Res. J., 2020: 9 doi: https://doi.org/10.54112/bcsrj.v2020i1.9]. 
intended use is not permitted by statutory regulation or exceeds the permitted use, you will need to obtain permission directly from the copyright holder. To view a copy of this licence, visit http://creativecommons.org/licen ses/by/4.0/.

(C) The Author(s) 2021

[Citation: Hayat, S., Naeem, M,. Ramzan, M., Zafarullah, M., Ahmad, I., Ali, Q., Malik, A. (2020). Study on zooplankton diversity during spring season in Chashma Lake, Pakistan. Biol. Clin. Sci. Res. J., 2020: 9 doi: https://doi.org/10.54112/bcsrj.v2020i1.9]. 